\title{
Effect of Molding and Machining on Neoflon CTFE M400H Polychlorotrifluoroethylene Rod Stock and Valve Seat Properties
}

\author{
Jess M. Waller \\ Project Leader, Honeywell Technology Solutions Inc., NASA Johnson Space Center White Sands Test Facility, \\ P. O. Box 20, Las Cruces, NM 88004 \\ 505-524-5249 \\ jwaller@wstf.nasa.gov \\ Barry E. Newton \\ Engineer, Wendell Hull \& Associates, Inc., 1020 South Main, Las Cruces, NM 88005 \\ 505-532-5623 \\ bnewton@.cs.com \\ Harold D. Beeson \\ Special Projects Manager, NASA Laboratories Office, NASA Johnson Space Center White Sands Test Facility, \\ P. O. Box 20, Las Cruces, NM 88004 \\ 505-524-5543 \\ hbeeson@wstf.nasa.gov
}

\section{Introduction}

Since 1997 numerous fires have been reported to the Food and Drug Administration involving cylinder valves installed on medical use oxygen cylinders sold and operated within the United States. All of the cylinder valves in question had polychlorotrifluoroethylene (PCTFE) valve seats. Subsequent failure analysis showed that the main seat was the primary source of ignition. A review of the incidents involving cylinder valve fires indicated three possible ignition mechanisms: contaminant promotion, flow friction, and resonance. However, gas purity analysis showed that uncombusted, residual oxygen was within specification. Infrared and energy dispersive spectroscopy further showed that no contaminants or organic compounds were present in the remaining, uncombusted valve seat material or on seat plug surfaces [1]. Therefore, contaminant-promoted ignition did not appear to be responsible for the failures.

Observations of extruded material along the outer edge of the coined or loaded seat area [1] produced by cylinder overuse or poppet overload led to concerns that accelerated gas flow across a deformed seat surface could generate enough localized heating to ignite the polymeric seat. Low molecular weight or highly amorphous quick-quenched PCTFE grades might be expected to be especially prone to this type of deformation. Such a failure mechanism has been described as "flow friction;" however, the corresponding mechanistic parameters are poorly understood.

Subsequent revelation of low-temperature dimensional instability by thermomechanical analysis (TMA) in a variety of PCTFE sheet and rod stock samples [1] led to new concerns that PCTFE valve seats could undergo excessive expansion or contraction during service. During expansion, additional extrusion and accompanying "flow friction" could occur. During contraction, a gap between the seal and adjacent metal surfaces could form. Gas flowing past the gap could, in turn, lead to resonance heating and subsequent ignition as described in ASTM Guide for Evaluation Nonmetallic Materials for Oxygen Service (G 63).

Attempts to uncover the origins of the observed dimensional instability were hindered by uncertainties about resin grade, process history, and post-process heat history introduced by machining, annealing, and sample preparation. An approach was therefore taken to monitor property changes before and after processing and machining using a single, well-characterized lot of Neoflon CTFE ${ }^{\circledR 1} \mathrm{M} 400 \mathrm{H}$ resin. A task group consisting of the current PCTFE resin supplier, two molders, and four valve seat manufacturers was formed, and phased testing on raw resin, intermediate rod stock, and finished valve seats initiated. The effect of processing and machining on the properties of PCTFE rod stock and oxygen gas cylinder valve seats was then determined. Testing focused on two types of extruded rod stock and one type of compression-molded rod stock. To accommodate valve seat manufacturer preferences for certain rod stock diameters, two representative diameters were used $(4.8 \mathrm{~mm}$ (0.1875 in.) and $19.1 \mathrm{~mm}(0.75 \mathrm{in})$.$) . To encompass a variety of possible sealing configurations, seven different$ valve seat types with unique geometries or machining histories were tested. The properties investigated were dimensional stability as determined by TMA, specific gravity, differential scanning calorimetry (DSC), compressive

\footnotetext{
${ }^{1}$ Neoflon ${ }^{\circledR}$ is a registered trademark of Daikin America, Inc., Orangeburg, New York.
} 
strength, zero strength time, and intrinsic viscosity. Findings are discussed in the context of polymer structure-process-property relationships whenever possible.

\section{Experimental}

Materials

Two commercial varieties of PCTFE were tested: Kel-F $81^{2}$ formulation 6060 in the form of pellets and $6.4 \mathrm{~mm}$ (0.25 in.) diameter rod stock; and Neoflon CTFE M400H in the form of coarse granular powder, $4.9 \mathrm{~mm}$ (0.1875 in.) and $19.1 \mathrm{~mm}(0.75 \mathrm{in}$.) diameter rod stock, and valve seats. The Kel-F 81 resin (lot \# 610) was obtained from NASA stock (Kennedy Space Center, FL) and had a reported starting zero strength time (ZST) of 401 sec. Kel-F 81 rod stock (Polyflon Corp., molded ca. 1979, lot unknown) was obtained from internal WSTF stock (ZST unknown). Neoflon CTFE M400H coarse granular powder (lot \# DFH4R99006) was obtained from Daikin America, Inc. (Orangeburg, NJ) and had a reported starting ZST of $411 \mathrm{sec}$. The Neoflon M400H resin was used to prepare all rod stock and valve seat specimens (Figure 1). All valve seats were received in free-standing condition, i.e., were not pressed into metal retainers.

Extruded rod stock was obtained from two molders (Molders 1 and 2) and compression-molded rod stock was obtained one molder (Molder 2). To accommodate valve seat manufacturer preferences for certain rod stock diameters, two representative diameters were supplied to valve seat manufacturers: $4.8 \mathrm{~mm}(0.1875 \mathrm{in}$.) and $19.1 \mathrm{~mm}(0.75 \mathrm{in})$. Of the $3.7 \mathrm{~m}$ (12 ft.) of each of the six types of rod stock manufactured for this study, $0.30 \mathrm{~m}$ $(1.0 \mathrm{ft}$.) was provided to White Sands Test Facility for thermal and mechanical property characterization, and $0.60 \mathrm{~m}$ (2.0 ft.) was provided to each of the participant valve seat manufacturers, the remainder was kept as reserve or allocated for other purposes.

To encompass a variety of oxygen regulator sealing configurations, testing was conducted on seven different valve seat types supplied by four valve seat manufacturers (Manufacturers 1,2,3, and 4). Valve seats with different machining processes were tested (Manufacturer 2, Processes 1 and 2), and different designs from the same manufacturer were tested (Manufacturer 3, Designs 1, 2, and 3). All valve seats were machined from $4.8 \mathrm{~mm}$ or $19.1 \mathrm{~mm}$ diameter rod stock except for valve seats from Manufacturer 2, which were machined from $6.4 \mathrm{~mm}$ (0.25 in.) diameter rod stock obtained by turning down $19.1 \mathrm{~mm}$ diameter rod stock (Figure 2).

\section{Molding Conditions}

Extruded rod (Molders 1 and 2) was molded in slightly oversized diameters and centerless ground to the desired finish tolerances. A metal jacket was used to support the larger diameter extruded rod, while the smaller diameter rod was extruded directly into air. All extruded rod tested was air cooled (versus water quenching). Compression-molded rod (Molder 2) was obtained by bandsaw cutting an $8.0 \mathrm{~mm}(0.31 \mathrm{in}$.) and $24.1 \mathrm{~mm}(0.95$ in.) thick sheet into rectangular bars, which were turned down on a lathe to $7.6 \mathrm{~mm}(0.30 \mathrm{in}$.) and $20.3 \mathrm{~mm}(0.80$ in.) diameter, annealed, and centerless ground to the final $4.9 \mathrm{~mm}$ and $19.1 \mathrm{~mm}$ diameters and finish tolerances. The same molding and follow-up pressures were used for both diameters of compression-molded rod.

\section{Thermal Analysis}

A Haake-Fisons (formerly Seiko) Model 120C Thermomechanical Analyzer equipped with a liquid nitrogen cooling accessory was used to measure dimensional stability. Specimens with diameters larger than could be accommodated by the TMA cell diameter $>10-\mathrm{mm}(0.39 \mathrm{in}$.)) were sectioned. Other details about specimen preparation appear elsewhere [1]. Dimensional stability was evaluated by cycling each specimen three times between -20 and $150{ }^{\circ} \mathrm{C}$, followed by measuring the permanent height change at $0{ }^{\circ} \mathrm{C}$. Melting $\left(T_{m}\right)$ and crystallization temperatures $\left(T_{c}\right)$, supercooling $\left(\Delta T=T_{m}-T_{c}\right)$, and heat of fusion $\left(\Delta H_{f}\right)$ and crystallization $\left(\Delta H_{c}\right)$ were determined using a TA Instruments Model 2920 DSC in accordance with procedures given in ASTM Test Method for Transition Temperatures and Heats of Transitions of Fluoropolymers by Differential Scanning Calorimetry (D 4591). Care was taken to sample rod stock and valve seat material from consistent locations with respect to the transverse (radial) direction. To minimize annealing, specimens $(10 \mathrm{mg})$ were ramped from ambient temperature to

\footnotetext{
${ }^{2} \mathrm{Kel}^{\circledR} \mathrm{F}^{\circledast}$ (obsolete) is a registered trademark of $3 \mathrm{M}$, St. Paul, MN.
} 


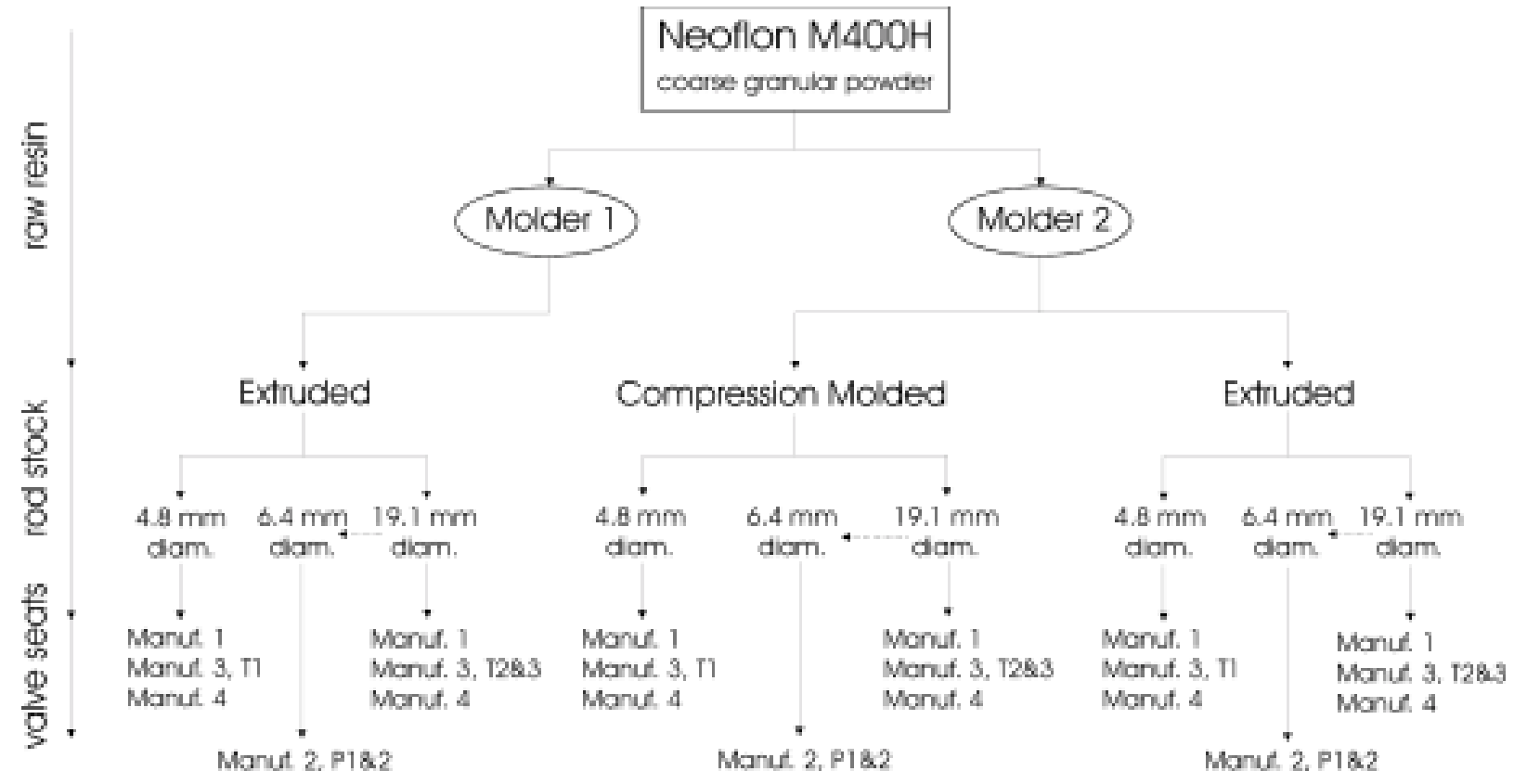

Figure 1 - Tracking chart showing allocation of Neoflon M400H PCTFE resin to molders, and molded rod stock to valve seat manufacturers (dashed lines indicate a latheing operation performed on rod stock)

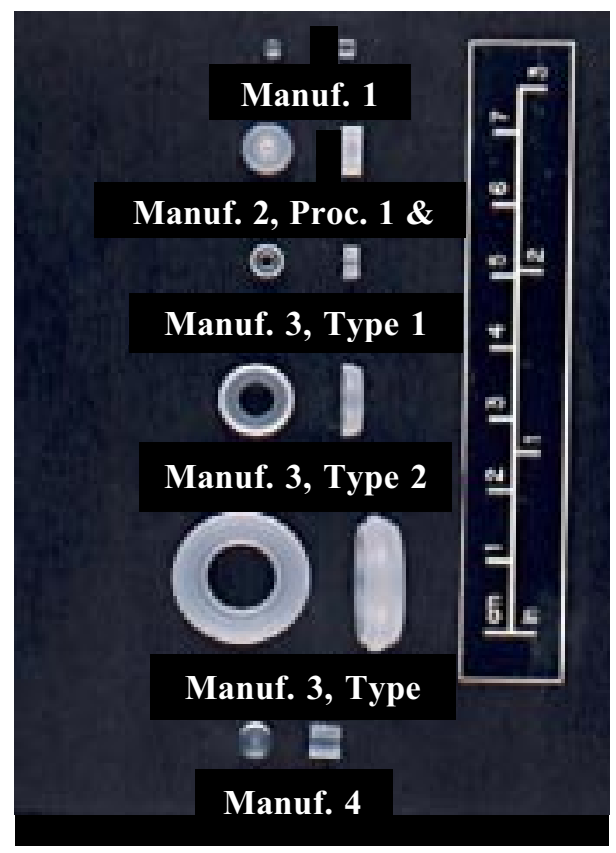

Figure 2 - PCTFE valve seat varieties used in oxygen cylinder applications 
$175^{\circ} \mathrm{C}$ at the maximum possible instrument heating rate $\left(\sim 125^{\circ} \min ^{-1}\right)$, then heated at a controlled rate of $10^{\circ} \min ^{-1}$ to $250^{\circ} \mathrm{C}$. All DSC determinations were conducted under nitrogen.

\section{Physical and Mechanical Property Evaluations}

Specific gravity was determined by ASTM Test Method for Specific Gravity of Plastics by Displacement (D 792) and weight percent crystallinity, $W^{c}$, calculated based on assumed values for the densities of pure amorphous and pure crystalline phases [2] according to the relationship:

$$
W^{c}=\frac{\rho_{c}}{\rho}\left(\frac{\rho-\rho_{a}}{\rho_{c}-\rho_{a}}\right) \times 100 \%
$$

Compressive strength at 25-percent strain was determined using an Instron ${ }^{\circledR}$ Model TTC Universal Tester and specimens with a 2:1 height:width ratio according to ASTM Test Method for Compressive Properties of Rigid Plastics (D 695).

ZSTs were determined per ASTM Standard Specification for Polychlorotrifluoroethylene (PCTFE) Plastics (D 1430-95) using $4.8 \mathrm{~mm}$ (0.1875 in.) wide by $1.6 \mathrm{~mm}$ (0.0625 in.) thick V-notched test strips machined directly from as-molded bar stock.

Intrinsic viscosity, [ $\eta$ ], was determined per ASTM Standard Practice for Diluted Solution Viscosity of Polymers (D 2857) at $130 \pm 0.2{ }^{\circ} \mathrm{C}$ in a DC550 silicone bath and using $98 \%$ 2,5-dichlorobenzotrifluoride (DCBTF, $t_{o}>150 \mathrm{sec}$ ) as the solvent. Dissolutions were carried out at $150^{\circ} \mathrm{C}$ in a micro-Ubbelohde viscometer for a minimum of $20 \mathrm{hr}$ under constant stirring to give an initial concentration of $0.5 \mathrm{~g} \mathrm{dL}^{-1}$. Extrapolation to infinite dilution allowed the number average molecular weight, $\bar{M}_{n}$, to be calculated using the Mark-Houwink equation and assumed values of $6.15 \times 10^{-5}$ and 0.74 for parameters $K$ and $a$, respectively [3]:

$$
[\eta]=K \overline{M_{n}^{a}}
$$

\section{Results and Discussion}

\section{PCTFE Grade Differences}

Initial efforts focused on evaluating the differences between the two principle grades of PCTFE resin historically used to manufacture oxygen gas cylinder valve seats, namely, Kel-F 81 and Neoflon CTFE. Since Kel-F 81 was emulsion-polymerized and Neoflon CTFE is suspension-polymerized, possible differences attributable to polymerization route were considered.

Emulsion polymerizations generally proceed more rapidly at a given temperature, and higher molecular weights are obtained than in suspension polymerizations conducted at the same rate [4]. This difference arises from isolation of the initiation step, which occurs in the aqueous phase, from the propagation and termination steps, which occur in the oil phase (dispersed micelles). In a suspension polymerization, the initiation, propagation, and termination steps all occur in the oil phase (dispersed monomer droplets). The suspension polymerization rate thus depends on initiator concentration, while the emulsion polymerization rate does not. Increasing the polymerization rate in a suspension polymerization by increasing initiator concentration produces more active chains competing for a finite amount of monomer, which can result in lower molecular weight. Both high polymerization rates and molecular weights can be achieved in emulsion polymerizations by increasing the micelle concentration [5]. Because the initiation rate, polymerization rate, monomer concentration, and micelle concentration remain relatively constant during much of an emulsion polymerization, resulting molecular weight is less affected by percent conversion. This usually results in a narrower molecular weight distribution (MWD) as defined by the polydispersity index $(=\bar{M} w \div \overline{M n}$ ) than obtained in a suspension polymerization [5]. Since many end-use properties have optimum values over a discrete molecular weight range, a broader MWD is generally undesirable from a practical applications standpoint.

A small batch emulsion process was used to produce Kel-F, requiring a combination of many batches to give a single lot, while a large single batch/single lot suspension processes is used to produce Neoflon CTFE [6]. Therefore, it is unclear if the polydispersity advantages inherent to the emulsion process are undermined by a combination of multiple batches to give a multimodal distribution. Last, the use dispersants and oil-soluble initiators in the suspension polymerization and fluorosurfactants [7] in the emulsion polymerization of PCTFE presents unique challenges during polymer isolation and purification. Although purity considerations are of paramount importance in oxygen applications, resin purity was not investigated in this study. 
DSC showed that the Neoflon M400H coarse granular powder underwent more supercooling $(\Delta T)$ and had a lower heat of crystallization $\left(\Delta T=38.8 \pm 1.2{ }^{\circ} \mathrm{C} ; \Delta H_{c}=12.8 \pm 0.9 \mathrm{~J} \mathrm{~g}^{-1}\right)$ than the Kel-F 81 pellets tested $\left(\Delta T=26.2 \pm 1.9^{\circ} \mathrm{C} ; \Delta H_{c}=14.4 \pm 0.4 \mathrm{~J} \mathrm{~g}^{-1}\right)$ (Figure 3). Broad MWD, low molecular weight, nucleating agents, or impurities can lower $\Delta T$; while low molecular weight is generally associated with high heats of crystallization [8]. The Kel-F 81 and Neoflon $\mathrm{M} 400 \mathrm{H}$ resins tested, however, did not contain nucleating agents [6]. Also, Kel-F 81 pellets had a higher heat of crystallization despite having a higher molecular weight $\left(M_{n}=712,000 \pm\right.$ $\left.25,000 \mathrm{~g} \mathrm{~mol}^{-1}\right)$ than the Neoflon $\mathrm{M} 400 \mathrm{H}$ coarse granular powder $\left(M_{n}=659,000 \pm 33,000 \mathrm{~g} \mathrm{~mol}^{-1}\right)$ (Figure 4).

These observations suggest that crystallization of Neoflon $\mathrm{M} 400 \mathrm{H}$ was suppressed by a broader MWD. Additional evidence of MWD broadening in the Neoflon $\mathrm{M} 400 \mathrm{H}$ resin is provided by the larger melting and crystallization peak widths at half height $\left(\mathrm{w}, \mathrm{m}=6.3{ }^{\circ} \mathrm{C}, \mathrm{w}, \mathrm{c}=6.8^{\circ} \mathrm{C}\right)$ compared to the Kel-F 81 resin $\left(\mathrm{w}, \mathrm{m}=3.8^{\circ} \mathrm{C}, \mathrm{w}, \mathrm{c}=\right.$ $5.0^{\circ} \mathrm{C}$ ) (Figure 3).
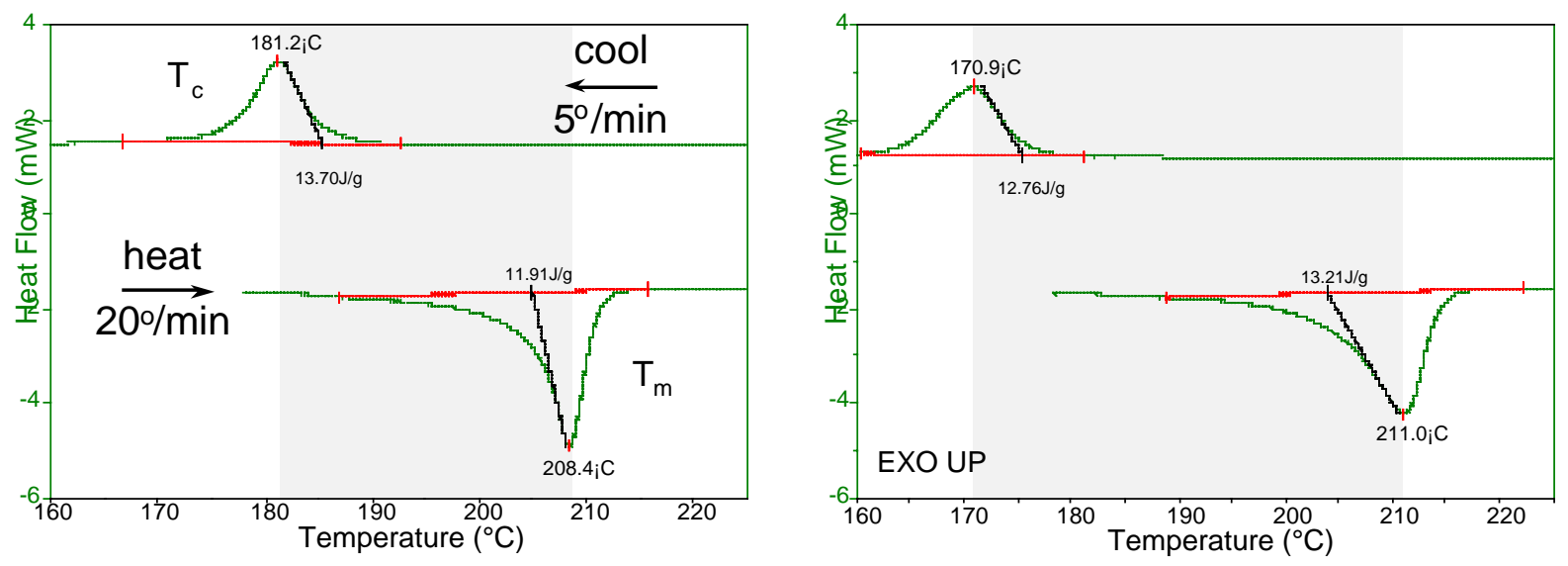

Figure 3 - Representative DSC thermograms showing lower supercooling and higher heat of crystallization for Kel-F 81 (left) versus Neoflon M400H (right)

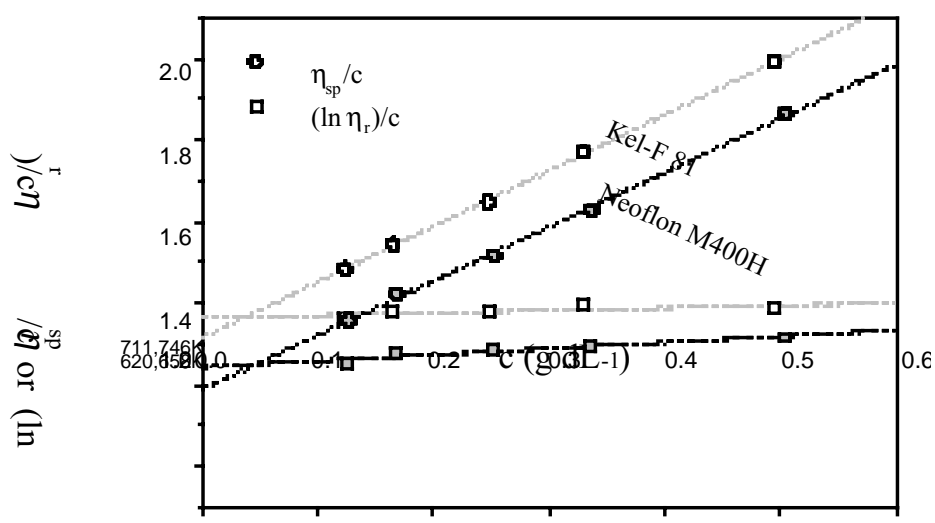

Figure 4 - Representative dilute solution viscosity data for as-polymerized Kel-F 81 and Neoflon M400H PCTFE 

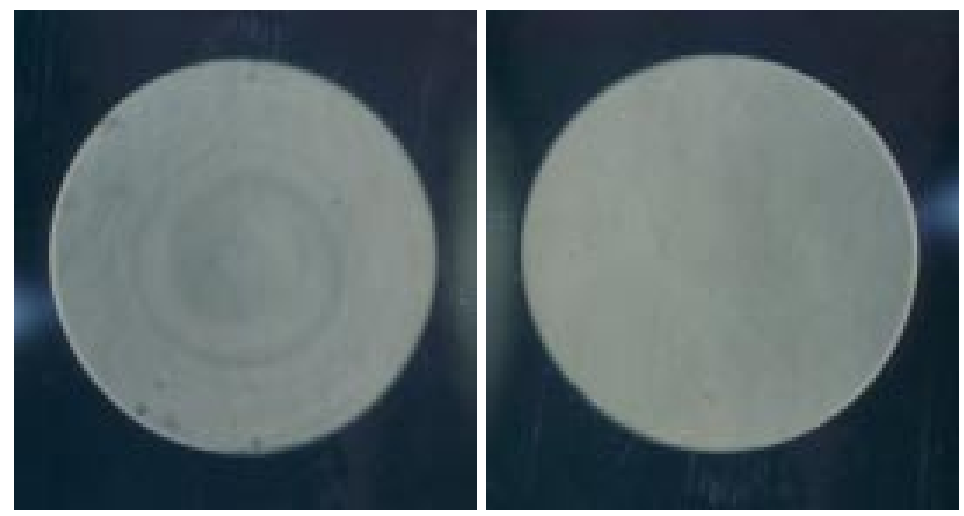

Figure 5 - Representative cross-sections of extruded (left) and compression-molded (right) Neoflon $\mathrm{M} 400 \mathrm{H}$ rod stock (19.1 mm (0.75 in.) diameter)

\section{Visual Appearance of Molded PCTFE Rod Stock}

All rod stock samples were identical in appearance except for visible differences in exterior and cross-sectional translucency. For example, extruded $4.8 \mathrm{~mm}$-diameter extruded rod stock from Molder 1 was noticeably more translucent than the extruded or compression-molded $4.8 \mathrm{~mm}$-diameter rod stock from Molder 2 (not shown). Inspection of $19.1 \mathrm{~mm}$-diameter rod stock cross-sections also revealed concentric, translucent swirls in the two extruded stocks, while no swirls were visible in the compression-molded stock (Figure 5). Also, there appeared to be several dark inclusions (located at six and seven o'clock in Figure 4, left, for example) in the extruded rod stock from Molder 2; however, no attempt was made to characterize the inclusions. Inspection of water (quick)-quenched and air (slow)-quenched compression-molded Neoflon M400H sheet has shown that translucent PCTFEs tend to be more amorphous, while more opaque PCTFEs tend to be more crystalline [9]. Crystallite (spherulite) size differences could also account for the observed variation in translucency.

\section{Effect of Process History on Rod Stock Properties}

Because of 1) the use of higher process temperatures during extrusion molding, 2) the well-known sensitivity of PCTFE to high process temperatures, and 3) the greater likelihood of molecular orientation (property anisotropy) and shear degradation (molecular weight reduction) during extrusion, it was suspected that extruded rod stock might exhibit a poorer balance of properties than compression-molded rod stock. Also, since heat is retained longer in the interior of larger molded articles, often leading to 'skin-core' morphology, the effect of rod stock diameter on property heterogeneity was investigated.

DSC, ZST, and intrinsic viscosity data on processed rod stock samples revealed significant increases in the heat of fusion and crystallization, accompanied by parallel drops in the ZST and number average molecular weight (Table 1, Figure 6). Unfortunately, the ZST does not appear to be very sensitive to molecular weight variation above a $\bar{M}_{n}$-threshold of approximately $600,000 \mathrm{~g} \mathrm{~mol}^{-1}$. The largest molecular weight decreases (-29 to -33 percent) were observed for extruded rod stock from Molder 1. The large decreases in ZST and molecular weight may be due to higher melt temperatures, excessively long residence times, or shear degradation during extrusion. The large increases in the heat of fusion ( +21 to +26 percent) observed for compression-molded rod stocks from Molder 2 may be due to the higher percent crystallinities developed during slow cooling under load (2.0 to $2.5 \mathrm{hr}$ ). The increases in the heat of fusion ( +14 to +16 percent) observed for extruded rod stock from Molder 1 may instead be due to the molecular weight decreases leading to increased chain flexibility in the melt. Little or no change was observed in the post-process values for $T_{m}, T_{c}$, and $\Delta T$ compared to the starting Neoflon M400H resin. The anomalous observation of a higher molecular weight for the $4.9 \mathrm{~mm}$ diameter compression-molded rod stock $\left(697,000 \mathrm{~g} \mathrm{~mol}^{-1}\right)$ compared to the starting resin $\left(659,000 \mathrm{~g} \mathrm{~mol}^{-1}\right)$ was attributed to data scatter and molecular weight variation within the lot of Neoflon M400H CTFE coarse granular powder used in this study. 
Table 1 - Properties of Molded PCTFE Rod Stock ${ }^{\mathrm{a}}$

\begin{tabular}{|c|c|c|c|c|c|c|c|}
\hline Property & $\begin{array}{l}\text { Starting } \\
\text { Resin }\end{array}$ & $\begin{array}{l}4.9 \mathrm{~mm} \\
\text { extruded, } \\
\text { Molder } 1\end{array}$ & $\begin{array}{l}19.1 \mathrm{~mm} \\
\text { extruded } \\
\text { Molder } 1\end{array}$ & $\begin{array}{r}4.9 \mathrm{~mm} \\
\text { extruded } \\
\text { Molder } 2\end{array}$ & $\begin{array}{l}19.1 \mathrm{~mm} \\
\text { extruded } \\
\text { Molder } 2\end{array}$ & $\begin{array}{l}4.9 \mathrm{~mm} \\
\text { compr.-mold } \\
\text { Molder } 2\end{array}$ & $\begin{array}{l}19.1 \mathrm{~mm} \\
\text { compr.-mold } \\
\text { Molder } 2\end{array}$ \\
\hline $\begin{array}{c}\Delta H_{f}\left(\mathrm{~J} \mathrm{~g}^{-1}\right) \\
\% \text { change }\end{array}$ & $13.9(1.1)$ & $\begin{array}{c}16.3(0.7) \\
+17\end{array}$ & $\begin{array}{c}15.8(0.3) \\
+14\end{array}$ & $\begin{array}{c}14.8(0.8) \\
+6\end{array}$ & $\begin{array}{l}15.4(0.9) \\
\quad+11\end{array}$ & $\begin{array}{c}16.8(0.1) \\
+21\end{array}$ & $\begin{array}{c}17.5(0.3) \\
+26\end{array}$ \\
\hline $\begin{array}{l}\Delta H_{c}\left(\mathrm{~J} \mathrm{~g}^{-1}\right) \\
\% \text { change }\end{array}$ & $12.8(0.9)$ & $\begin{array}{l}16.0(0.6) \\
+25\end{array}$ & $\begin{array}{c}14.9(0.9) \\
+16\end{array}$ & $\begin{array}{c}15.7(1.0) \\
+23\end{array}$ & $\begin{array}{l}14.7(1.4) \\
+15\end{array}$ & $\begin{array}{c}14.4(0.2) \\
+13\end{array}$ & $\begin{array}{c}14.0(0.3) \\
+9\end{array}$ \\
\hline$W^{c}(\%)$ & $\ldots$ & $61(9)$ & $62(1)$ & $42(9)$ & $58(1)$ & $61(9)$ & $66(3)$ \\
\hline ZST (s) & $411^{b}$ & $205(1)$ & $276(6)$ & $410(5)$ & $392(1)$ & $414(4)$ & 407 (7) \\
\hline $\begin{array}{l}\bar{M}_{n}\left(\cdot 10^{-6} \mathrm{~g} \mathrm{~mol}^{-1}\right)^{\mathrm{c}} \\
\quad \% \text { change }\end{array}$ & $6.59(0.33)$ & $\begin{array}{l}4.41 \\
-33\end{array}$ & $\begin{array}{l}4.70 \\
-29\end{array}$ & $\begin{array}{c}6.01 \\
-9\end{array}$ & $\begin{array}{c}6.37 \\
-3\end{array}$ & $\begin{array}{l}6.97 \\
+6\end{array}$ & $\begin{array}{l}6.56 \\
\mathrm{NC}\end{array}$ \\
\hline $\begin{array}{l}M_{n}\left(\cdot 10^{-6} \mathrm{~g} \mathrm{~mol}^{-1}\right)^{\mathrm{d}} \\
\quad \% \text { change }\end{array}$ & $\cdots$ & $\cdots$ & $\begin{array}{c}\text { TBD } \\
-/+\end{array}$ & $\cdots$ & $\begin{array}{c}\text { TBD } \\
-/+\end{array}$ & $\ldots$ & $\begin{array}{c}\text { TBD } \\
-/+\end{array}$ \\
\hline$\sigma_{\mathrm{c}, 25 \%}(\mathrm{MPa})$ & $\cdots$ & $68(<1)$ & $95(<1)$ & $72(<1)$ & $83(1)$ & $79(2)$ & $92(6)$ \\
\hline \multicolumn{8}{|c|}{$\begin{array}{l}\text { a Abbreviations used: heat of fusion }\left(\Delta H_{f}\right) \text {, heat of crystallization }\left(\Delta H_{c}\right) \text {, weight percent crystallinity }\left(W^{c}\right) \text {, zero } \\
\text { strength time (ZST), number average molecular weight }\left(\bar{M}_{n}\right) \text {, no change (NC); measurement not performed }\end{array}$} \\
\hline \multicolumn{8}{|c|}{$\begin{array}{l}\text { b Starting resin ZST was determined on molded bars and therefore does not correspond to the molecular } \\
\text { weight of the unprocessed coarse granular powder. }\end{array}$} \\
\hline
\end{tabular}
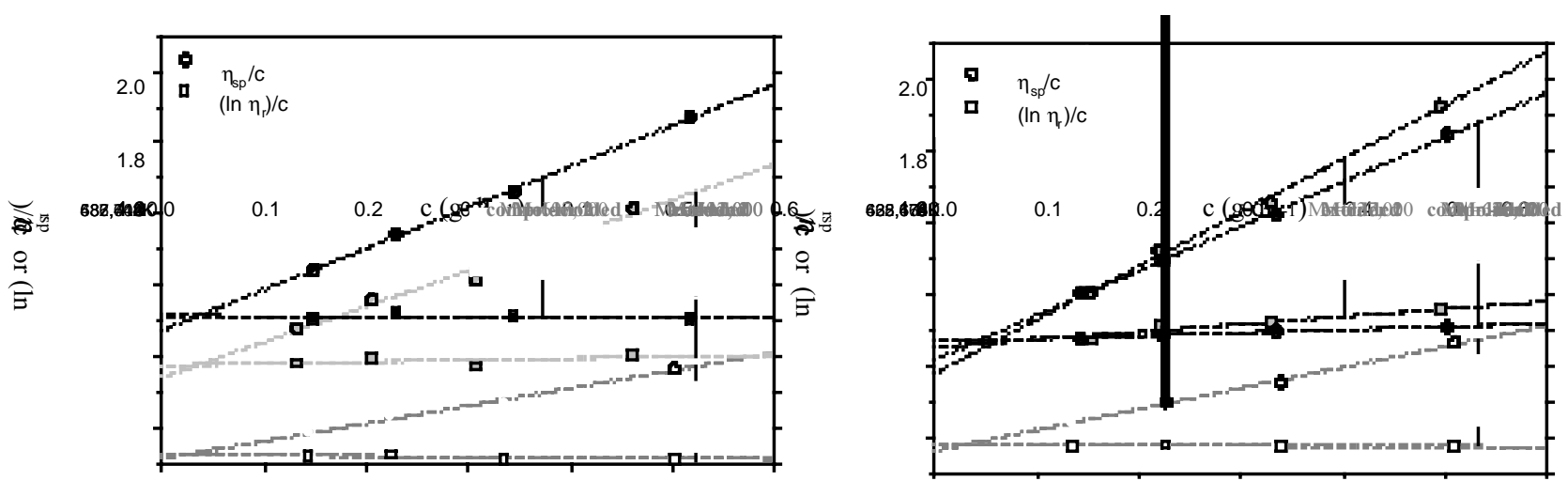

Figure 6 - Dilute solution viscosity data for $4.9 \mathrm{~mm}$ (0.1875 in.) (left) and $19.1 \mathrm{~mm}$ (0.75 in.)(right) diameter Neoflon M400H PCTFE rod stock 


\section{Representative 3/16 in. diameter rod}
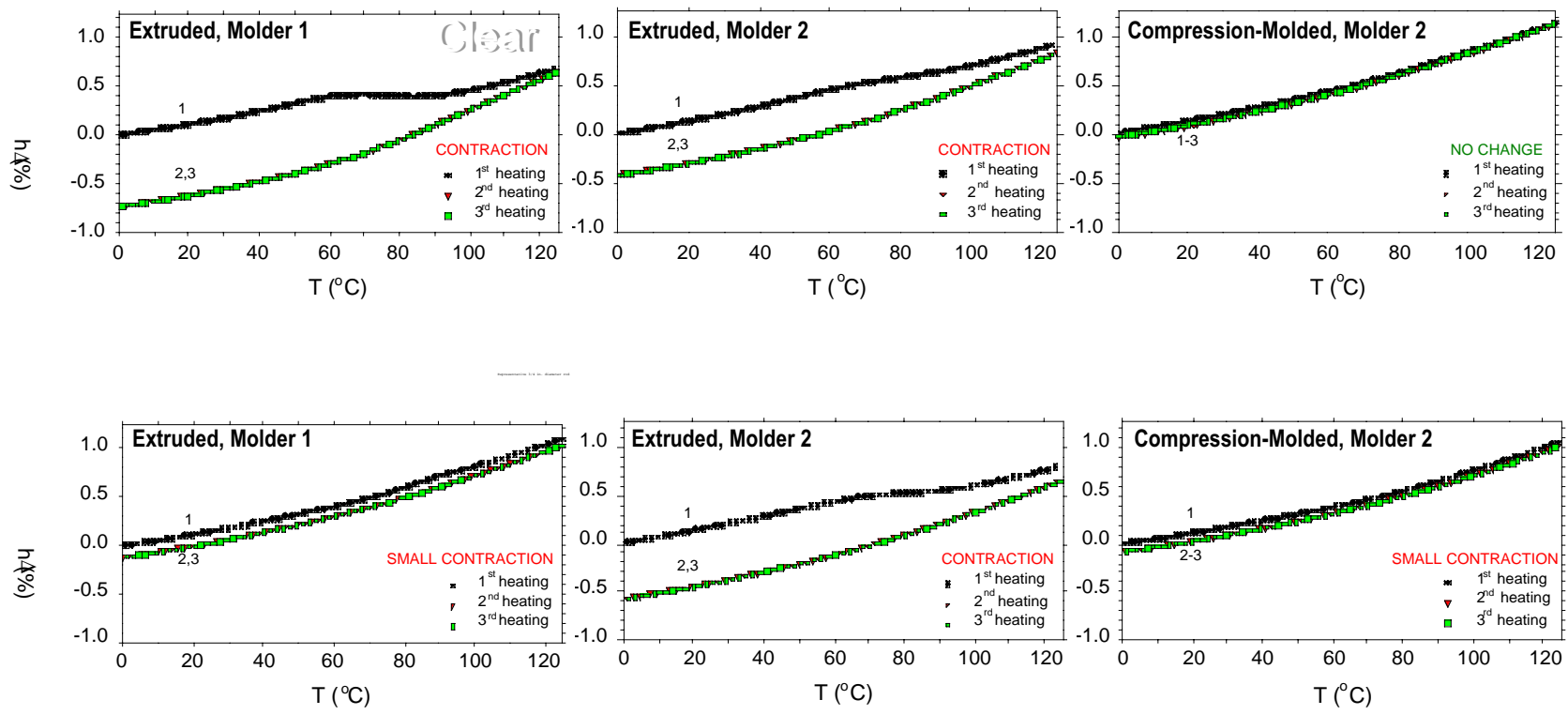

Figure 7 - TMA thermograms showing the effect of thermal cycling on the permanent height change of $4.9 \mathrm{~mm}$ (0.1875 in.) (top) and $19.1 \mathrm{~mm}$ (0.75 in.)(bottom) diameter Neoflon M400H PCTFE rod stock

The effect of skin-core molecular weight variation in the thicker $19.1 \mathrm{~mm}$ diameter rod stock was examined by comparing the intrinsic viscosity of specimens taken from the outside edge of the rod (next-to-last row, Table 1). Results showed significant molecular weight segregation in the extruded rod stock, but virtually no segregation in the compression-molded rod stock.

\section{Dimensional Stability of Rod Stock}

The compressive strength (at 25-percent strain) of the $4.9 \mathrm{~mm}$ diameter rod stock was found to follow ZST, molecular weight, and dimensional stability (Table 1, last row), while the compressive strength of the $19.1 \mathrm{~mm}$ diameter rod stock was found to follow dimensional stability. This lack of correlation between the compressive strength and other properties appears to derive from the use of an annealing step by Molder 1 to give a strong, dimensionally stable material despite having a low ZST (276 s) (Figure 7, lower left-hand corner). By comparison, the extruded $19.1 \mathrm{~mm}$ diameter rod stock from Molder 2 was unannealed, but had a lower compressive strength despite having a higher ZST (392 s) (Figure 7, lower center). At temperature below $150{ }^{\circ} \mathrm{C}\left(300^{\circ} \mathrm{F}\right)$, annealing can be used to relieve localized stresses within the amorphous phase as well as enhance crystal perfection (secondary crystallization). If conducted at temperatures near $175^{\circ} \mathrm{C}\left(375^{\circ} \mathrm{F}\right)$, at which the maximum crystallization rate occurs, annealing can result in increased percent crystallinity (primary crystallization). These observations suggest annealing can be used to improve dimensional stability and mechanical strength under load. Such property enhancements may be particularly important in valve applications requiring close tolerances to be maintained over nominal temperature excursions. Annealing may even compensate for the adverse effects of molecular weight degradation caused by non-optimized processing.

Previously published data [1] shows considerable variation in the permanent height change as measured by TMA caused by thermal cycling of several varieties of PCTFE, including valve seats taken from oxygen and corrosive gas service, as well as molded bar stock and sheet. These materials exhibited permanent expansions as high as +3.9 percent and permanent contractions as low as -8.5 percent following repetitive thermal cycling between $-20^{\circ} \mathrm{C}\left(-4^{\circ} \mathrm{F}\right)$ and $150^{\circ} \mathrm{C}\left(300^{\circ} \mathrm{F}\right)$. Furthermore, dimensional relaxation was observed as evidenced by the appearance of inflections or maxima as low as $37^{\circ} \mathrm{C}\left(99^{\circ} \mathrm{F}\right)$ in the height versus temperature curve during the first 


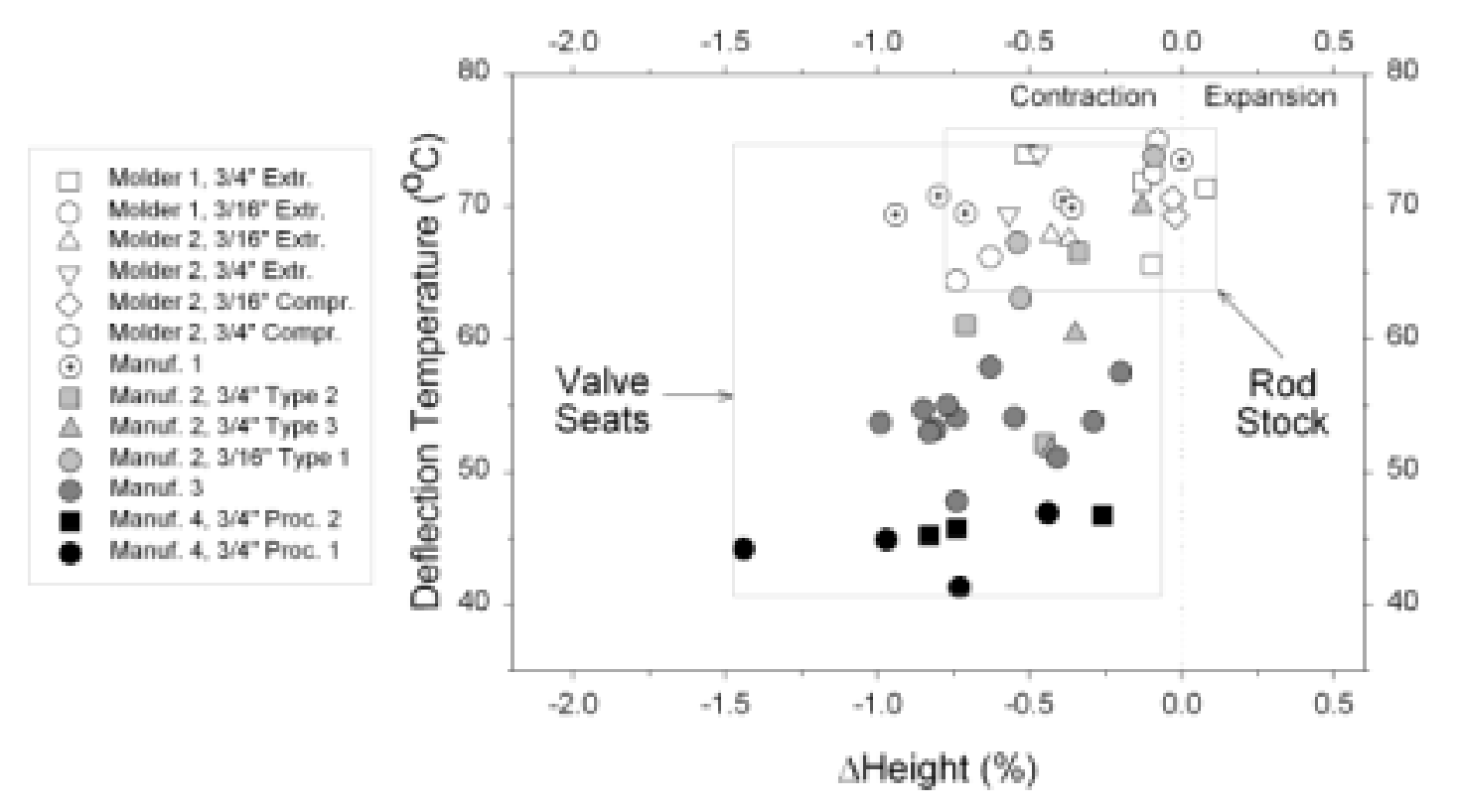

Figure 8 -Scatter plot showing the distribution of deflection temperature and net height change for molded rod stock (open symbols) and machined valve seats (filled symbols)

heating. The close correspondence of the low temperature TMA deflections with the glass transition, which has a published value of ca. $52^{\circ} \mathrm{C}\left(126^{\circ} \mathrm{F}\right)$ per DIN 53736 [10], suggests the deflections originate from molecular relaxation within the amorphous phase.

By comparison, the TMA deflection data distribution for the molded rod stock used in this study was narrower; permanent expansions as high as +0.08 percent and permanent contractions as low as -0.74 percent were observed (Figure 8). Also, the inflections or maxima indicative of dimensional relaxation occurred at higher temperatures; between $64.4\left(148^{\circ} \mathrm{F}\right)$ and $75.0^{\circ} \mathrm{C}\left(167^{\circ} \mathrm{F}\right)$.

\section{Effect of Machining on Valve Seat Properties}

Final efforts focused on determining the effect of machining on valve seat properties. The final properties of semicrystalline thermoplastics such as PCTFE are governed by the cumulative heat history. Most heat history is introduced during processing (melting). However, significant heat history can also be introduced during post-process operations, such as latheing and machining, or pressing of seats into metal retainers at temperature. Attempts were therefore made to determining the effect of post-process heat histories on valve seat properties.

Inspection of Figure 8 also shows that TMA valve seat data tended to be grouped according to seat manufacturer, especially for Manufacturers 1 and 3. The TMA deflection data distribution for the machined valve seats was also shifted to larger percent contractions (contractions as large as -1.44 percent were observed) (Figures 8 and 9), and the deflections observed during first heatings occurred at lower temperatures; for example, inflections or maxima as low as $41.3{ }^{\circ} \mathrm{C}\left(106^{\circ} \mathrm{F}\right)$ were observed. The reasons behind these shifts are unclear; however, the largest shift was observed for the valve seats supplied by Manufacturer 4 (Figure 8, black symbols). These valve seats happened to have been subjected to the greatest amount of machining, involving turning down of the $19.1 \mathrm{~mm}$ to $6.4 \mathrm{~mm}$ diameter rod stock (Figure 1). Efforts are underway to determine the effect of lathe speed, heat treatments, cutting tool materials, and cutting fluids, on finished valve seat properties.

Another reason for the shift of the TMA data towards larger percent contraction and lower deflection temperature could be the 'skin-core' morphological heterogeneity and choice of TMA sampling location. For example, the valve seats from Manufacturer 2 were obtained from the middle of the $19.1 \mathrm{~mm}$ diameter rod stock (Figure 9, also see Figure 5) were noticeably clearer in appearance, similar to the $4.9 \mathrm{~mm}$ diameter extruded rod from Molder 1 which exhibited the poorest dimensional stability of all the rod stock materials examined in this study (Figure 7, top left). Lower crystallinity does not appear to be a reason for the increased translucency, since the middle of the $19.1 \mathrm{~mm}$ diameter rod stock would be expected to be more crystalline due to retention of heat for longer periods during solidification from the melt. However, DSC measurements on the finished valve seats had not 


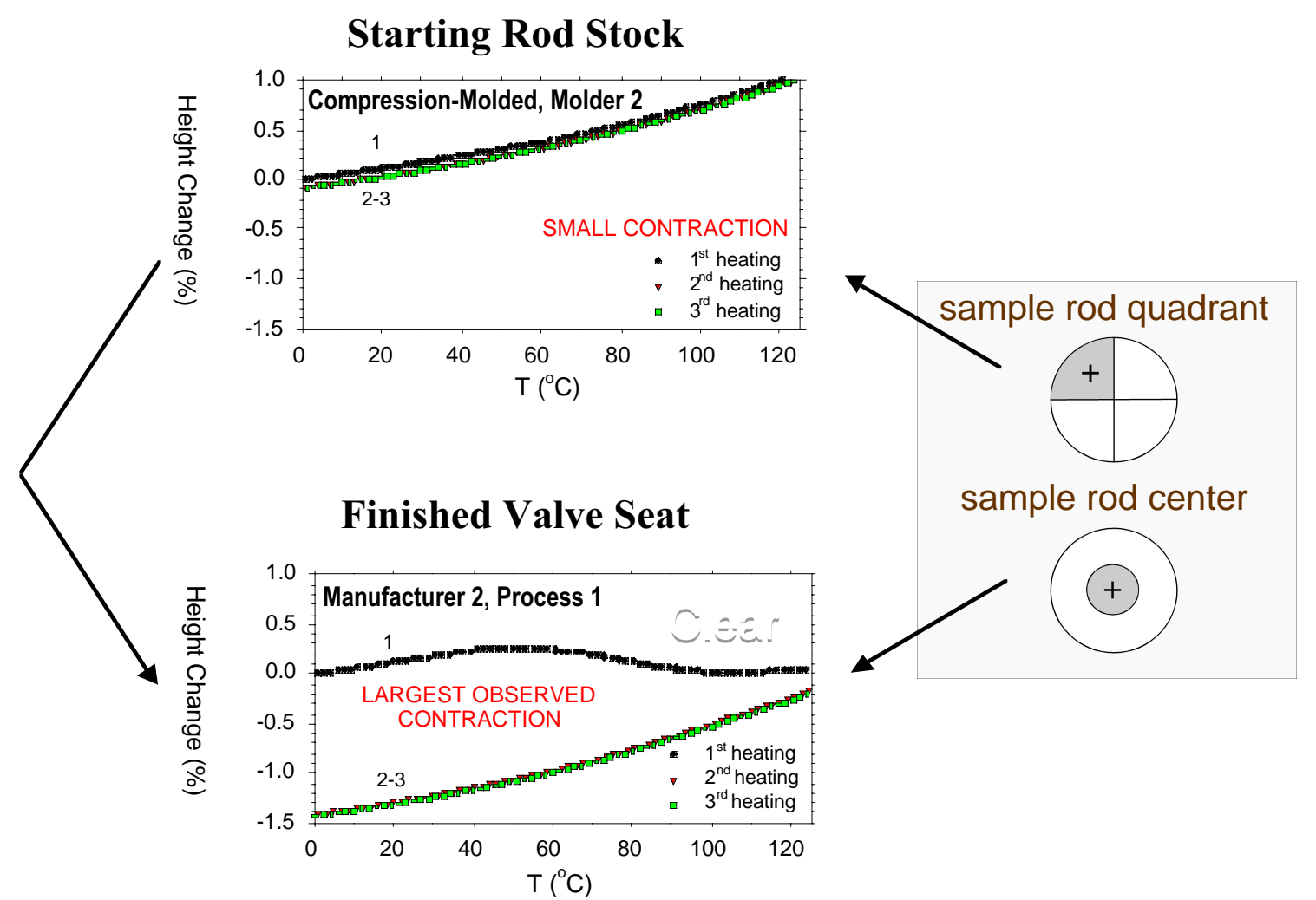

Figure 9 - TMA thermograms showing different dimensional stability of the molded rod stock (top) versus machined valve seats (bottom) fabricated from it

been conducted at the time of this report, nor had crystallite size been evaluated by polarized light microscopy. The possible effect of molecular weight on translucent appearance and low dimensional stability was investigated, but did not appear to be much of a contributing factor either. For example, the $\overline{M n}$ of the valve seat in question that gave the large deflection (Figure 9) was $614,000 \mathrm{~g} \mathrm{~mol}^{-1}$, which is only slightly less than the $656,000 \mathrm{~g} \mathrm{~mol}^{-1}$ value measured for the starting bar stock (Table 1).

\section{Conclusions}

The effect of processing and machining on the properties of polychlorotrifluoroethylene (PCTFE) rod stock and oxygen gas cylinder valve seats was determined. Testing focused on two types of extruded rod stock and one type of compression-molded rod stock. Conclusions may be summarized as follows:

- $\quad$ DSC gave evidence of possible MWD differences between emulsion-polymerized Kel-F 81 and suspension-polymerized Neoflon $\mathrm{M} 400 \mathrm{H}$, which may in turn have important property ramifications.

- $\quad$ Processing led to significant increases in the heat of fusion and crystallization, accompanied by parallel drops in the ZST and number average molecular weight.

- $\quad$ The properties of PCTFE rod stock varied significantly depending on the molding process (extrusion vs. compression-molding) and molding conditions used (Molder 1 versus 2).

- $\quad$ Annealing may compensate for the adverse effects of molecular weight degradation caused by non-optimized processing.

- $\quad$ Although good correlation was obtained between ZST and intrinsic viscosity data, ZST does not appear to be very sensitive to molecular weights above a $\overline{M^{n}}$-threshold of approximately $600,000 \mathrm{~g} \mathrm{~mol}^{-1}$.

- $\quad$ TMA data for valve seat and valve seats diverged. The reasons for this divergence could be property variation within a given rod, machining differences, or 'skin-core' morphology and choice of sampling location. 
- $\quad$ TMA valve seat data tended to be grouped by seat manufacturer, suggesting dimensional stability was affected by machining process differences.

- $\quad$ Sample translucency appears to be related dimensional stability.

\section{Acknowledgments}

The authors are indebted to P. Spencer (WSTF) and B. Wolle (WSTF) for mechanical properties evaluations, B. Greene (WSTF) and D. Mast (WSTF) for DSC work, Anna De Armond (WSTF) for help with intrinsic viscosity measurements, and R. Frentz (Afton Plastics) for providing the ZST data.

\section{References}

[1] Waller, J. M., Newton, B. E., Haas, J. P., Beeson, H. D., "Comparison of the Dimensional Stability of Kel-F 81 and Neoflon CTFE M400H Polychlorotrifluoroethylenes used in Valve Seat Applications,"

Flammability and Sensitivity of Materials in Oxygen-Enriched Atmospheres: Eighth Volume, ASTM STP

1395, T. A. Steinberg, H. Barthelemy, Beeson, H. D., Newton, B. E., Eds., American Society for Testing and Materials, West Conshohocken, PA, 2000.

[2] Hoffman, J. D., Weeks, J. J., "The Specific Volume and Degree of Crystallinity of Polychlorotrifluoroethylene," J. Polymer Sci., 1958, 28(117), 472-475.

[3] Walsh, E. K., Kaufman, H. S., "Intrinsic Viscosity-Molecular Weight Relationship for Polychlorotrifluoroethylene," J. Polymer Sci., 1957, 26, 1-7.

[4] Flory, P. J., "Copolymerization, Emulsion Polymerization, and Ionic Polymerization," Principles of Polymer Chemistry, Cornell University Press, Ithaca, NY, Chapter V, 1986.

[5] Odian, G., "Emulsion Polymerization," Principles of Polymerization, 2nd Edition, John Wiley and Sons, New York, NY, Chapter 4, 1981.

[6] Lin, G. private communication, Daikin America, Inc., April 2002.

[7] Chandrasekaran, S., "Chlorotrifluoroethylene Polymers," Encyclopedia of Polymer Science and Engineering, 2nd Edition, Kroschwitz, J. I., Editor-in-Chief, John Wiley and Sons, New York, NY, Vol. 3, 473, 1990.

[8] Shalaby, S. W., "Thermoplastic Polymers," Thermal Characterization of Polymeric Materials, Chapter 3, Turi, E. A., Ed., Academic Press, Inc., 1981.

[9] Waller, J. M., Haas, J. P., Beeson, H. D., "Polymer-Oxygen Compatibility Testing: Effect of Oxygen Aging on Ignition and Combustion Properties," Flammability and Sensitivity of Materials in Oxygen-Enriched Atmospheres: Ninth Volume, ASTM STP 1395, T. A. Steinberg, H. D. Beeson, B. E. Newton, Eds., American Society for Testing and Materials, West Conshohocken, PA, 2000.

[10] Tecaflon PCTFE, Technical Data Sheet, Ensinger GbbH \& Co., Rudolf-Diessel Str. 8, Nufringen, Germany, 2000. 